1 ANALYTICAL SCIENCE

7 \& TECHNOLOGY

Vol. 25, No. 6, 350-363, 2012

http://dx.doi.org/10.5806/AST.2012.25.6.350

\title{
Uncertainties of ionic species in snowpit samples determined with ion chromatography system
}

\author{
Sang-bum Hong ${ }^{\star}$, Soon-do Hur, Sun-Mee Kim¹, Sungmin Hong ${ }^{2}$, \\ Ji-woong Chung, Namgoo Kang ${ }^{3}$ and Chang-Hee Kang ${ }^{4}$ \\ Division of Polar Earth-System Sciences, Korea Polar Research Institute, Kordi \\ ${ }^{1}$ Environmental Policy Research Group/Division of Water Environment, Korea Environment Institute (KEI) \\ ${ }^{3}$ Division of Metrology for Quality of Life, Korea Research Institute of Standard Science \\ ${ }^{4}$ Department of Chemistry, Jeju National University \\ (Received June 1, 2012; Revised October 12, 2012; Accepted October 19, 2012)
}

\section{이온크로마토그래피 시스템을 이용한 눈 시료의 이온성분 측정자료의 불확도 산출}

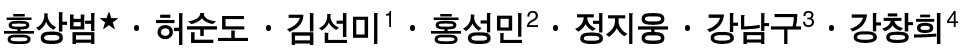 \\ 한국해양연구원 부설 극지연구소 지구시스템연구부, ${ }^{1}$ 한국환경정책평가연구원 정책연구본부물환경연구실 \\ 2인하대학교 해양학부, ${ }^{3}$ 한국표준과학연구원 삶의질표준본부, ${ }^{4}$ 제주대학교 화학과 \\ (2012. 6. 1. 접수, 2012. 10. 12. 수정, 2012. 10. 19. 승인)
}

\begin{abstract}
To determine ionic species in snowpit samples using ion chromatography system, we described the performance of ion chromatography(IC) system, cleaning method of bottle, and interference by filtering procedure. The limit of detection, reproducibilities, and accuracies determined with $\mathrm{BCR}^{\circledR}-408$ were 0.01 $0.26 \mu \mathrm{g} / \mathrm{L}, 0.4-17.4 \%, 4.5-12.0 \%$ for cations and $0.02-0.26 \mu \mathrm{g} / \mathrm{L}, 0.1-27.6 \%, 1.3-5.6 \%$ for anions, respectively. Lab blank test for sample bottle indicated that $\mathrm{CH}_{3} \mathrm{CO}_{2}{ }^{-}, \mathrm{HCO}_{2}{ }^{-}$, and $\mathrm{NH}_{4}{ }^{+}$can be easily contaminated in the lab environment. The positive interferences of $\mathrm{NO}_{3}{ }^{-}$were partly attributed to the cleaning method of bottle. The filtering of melted snow sample should be carefully applied because it can positively affect the concentration levels of some ionic species. Finally, this method was applied to measure ionic species in snowpit samples from the upward area near NEEM camp and the uncertainties of measurement data of $\mathrm{F}^{-}$were also estimated.

요 약: 이온크로마토그래피(IC) 시스템을 이용하여 눈 시료의 이온성분을 측정하기 위해 IC 시스템의 성능평가, 시료 병의 세척법, 필터 적용에 따른 문제점을 조사하였다. 이를 바탕으로 이온성분 측정자료 의 불확도 산출법을 연구하였다. 본 연구의 IC 시스템 검출한계는 양이온의 경우 $0.01 \sim 0.26 \mu \mathrm{g} / \mathrm{L}$, 음이 온 성분들은 $0.02 \sim 0.26 \mu \mathrm{g} / \mathrm{L}$ 로 나타났다. 그리고 양이온과 음이온의 재현성을 나타내는 변동계수는 각각 $0.4-17.4 \%, 0.1-27.6 \%$ 로 조사되었다. $\mathrm{BCR}^{\circledR}-408$ 을 이용한 측정자료의 정확도 조사 결과 양이온과 음이온 의 상대오차는 각각 $4.5-12.0 \%, 1.3-5.6 \%$ 로 나타났다. 시료 병에 대한 실험실 바탕시험 결과 유기음이온
\end{abstract}

Corresponding author

Phone : +82-(0)32-260-6146 Fax : +82-(0)32-260-6149

E-mail : hong909@kopri.re.kr 
을 포함한 일부 성분들 $\left(\mathrm{CH}_{3} \mathrm{CO}_{2}^{-}, \mathrm{HCO}_{2}^{-}, \mathrm{NH}_{4}^{+}\right)$의 경우 다른 성분들에 비해 오염 가능성이 높은 것으로 조사되었다. $\mathrm{NO}_{3}^{-}$성분의 바탕시험 결과는 시료 병 세척과정에 사용된 $\mathrm{HNO}_{3}$ 의 잔류에 따른 오염영향으 로 나타났다. 그리고 눈 시료 용융액의 불용성 입자를 제거하기 위해 필터를 사용할 경우 일부 이온 성 분들은 필터로부터 직접 용출되는 것으로 조사되었다. 따라서 사용 전에 증류수 $(\sim 6 \mathrm{~mL})$ 로 세척하는 것 이 필요하고 지역별로 눈 시료의 농도 특성을 고려하여 선별적으로 필터를 적용해야 한다. 마지막으로 그린란드 북서부 내륙의 NEEM 캠프의 풍상 지역에서 채취한 눈 시료의 이온성분 측정 자료의 불확도 를 산출하기 위해 이온 성분 가운데 $\mathrm{F}^{-}$측정 자료에 대해 불확도를 결정하였다.

Key words: Ion chromatography system, snow, ice, uncertainties of measurement data

\section{1. 서 론}

극 지역 눈과 빙하의 이온성분은 다양한 발생과정 을 거쳐 대기환경에 유입된 미세먼지와 가스로부터 유래한다. 따라서 이들 성분의 농도 변화 특성은 미 세먼지와 가스의 발생원과 발생량, 이들의 수송과정 및 대기화학 반응, 침강 과정 등의 특성을 다양하게 반영할 수 있다. 해양과 토양에서 직접 발생하는 미 세먼지는 해염 성분 $\left(\mathrm{ss}-\mathrm{Na}^{+}, \mathrm{Cl}^{-}, \mathrm{ss}-\mathrm{Mg}^{2+}\right)$ 과 지각 성

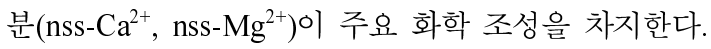
이들은 물리적 과정에 의해 생성되며 입자의 직경이 $2.5 \mu \mathrm{m}$ 이상인 미세먼지의 영역에 주로 존재한다. 그 리고 연소과정과 가스상 전구물질이 물리, 화학적 변 환 경로를 거쳐 생성되는 성분들은 직경이 $2.5 \mu \mathrm{m}$ 미만의 미세먼지 영역에 주로 분포한다. ${ }^{1}$ 여기에는 대표적으로 생물소각(biomass burning) 과정에서 직 접 배출되는 $\mathrm{K}^{+}$과 해양 미생물에 의해 생성되는 Dimethylsulfide(DMS)의 대기화학반응에 의해 생성되

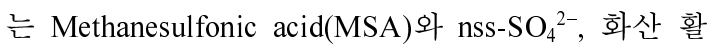
동(volcanic activity)에 의해 방출된 $\mathrm{SO}_{2}$ 로부터 생성

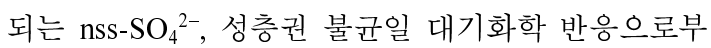
터 생성되는 $\mathrm{NO}_{3}^{-}$등이 보고되고 있다. ${ }^{2}$ 따라서 극 지역 눈과 빙하의 $\mathrm{nss}-\mathrm{SO}_{4}{ }^{2-}$ 은 화산 활동과 해양 미 생물의 활동에 의한 영향을 동시에 고려해야 한다. 이 가운데 화산 활동은 해양 미생물의 활동에 의한 영향에 비해 단기적인 농도 변화에 기여하는 유입경 로로 조사되고 있다. ${ }^{2}$

대기환경의 미세입자나 화학적 비반응성 가스들은 발생원 주변뿐만 아니라 장거리 이동으로 지역적 혹 은 전 지구적인 대기환경에 영향을 미칠 수 있다. 따 라서 인간의 활동이 미미한 극 지역의 대기환경 특성 을 이해하기 위해서는 극 지역 주변의 발생원뿐만 아 니라 장거리 이동과정을 통해 유입되는 대기 구성물
질의 영향을 파악하는 것이 매우 중요하다. 대표적으 로 아시아 대륙과 북아메리카 지역으로부터 발생한 지각기원의 미세입자는 북반구 중위도 편서풍의 영 향으로 그린란드 지역까지도 수송이 가능하다. 또한 아르헨티나 남부의 반 건조성 고원인 파타고니아 (Patagonia) 지역에서 발생한 먼지는 남극 대륙 주변 의 서풍에 의해 남극대륙으로 장거리 수송이 가능한 것으로 알려지고 있다. ${ }^{3}$ 극 지역으로 수송된 미세먼 지와 가스들은 침강 과정을 통해 극 지역의 대기환경 으로부터 제거된다. 결국 극 지역의 외부에서 유입되 는 미세먼지와 가스의 장거리 수송 과정은 대기 순환 과 바람의 세기 등과 밀접한 관계가 있으므로 눈과 빙하의 이온성분들의 조성과 농도특성은 침강 시기 의 대기환경과 기후요소 특성을 나타나게 된다.

눈과 빙하의 이온성분을 이용하여 과거의 대기환 경과 기후변화를 복원한 선행연구 결과를 살펴보면, 남극대륙 주변의 대기순환을 지시하는 지시성분으로 해염성분 $\left(\mathrm{Na}^{+} \& \mathrm{Cl}^{-}\right), \mathrm{Ca}^{2+}, \mathrm{NO}_{3}^{-}$, 그리고 $\mathrm{MSA}$ 성분 들을 주로 사용하고 있다. ${ }^{2}$ 또한 $\mathrm{Na}^{+}$과 $\mathrm{MSA}$ 성분은 과거 극 지역 빙붕(ice sheet) 주변의 바다얼음(sea ice)의 규모 변화를, $\mathrm{nss}^{-} \mathrm{SO}_{4}{ }^{2-}$ 와 $\mathrm{F}^{-}$는 과거 화산 활동 을 지시할 수 있는 대표적인 성분으로 알려지고 있다. ${ }^{2}$ 또한 $\mathrm{NO}_{3}{ }^{-}, \mathrm{NH}_{4}{ }^{+}, \mathrm{nss}_{-} \mathrm{SO}_{4}{ }^{2-}$ 은 산업혁명 이후 급격히 증가한 인간의 산업 활동이 대기환경에 미친 영향을 평가하기 위해 북극 그린란드 지역과 중위도 고산 지 역의 눈과 빙하에서 흔히 사용되는 이온성분들이다. ${ }^{4}$

극 지역 눈과 빙하의 이온성분들은 sub- $\mu \mathrm{g} / \mathrm{L}$ 에서 sub-mg/L 수준으로 보고되고 있다. 특히 남극대륙 빙 하의 이온성분들의 농도 범위는 sub- $\mu \mathrm{g} / \mathrm{L}$ 에서 수십 $\mu \mathrm{g} / \mathrm{L}$ 수준으로 나타났다. ${ }^{4-16}$ 이에 반해 그린란드 지 역을 포함한 북극 지역, 저위도와 중위도에 있는 고 산지역 눈과 빙하의 이온성분은 남극대륙보다 상대 적으로 농도가 높은 수준이다(Table 1-2). 극 지역 눈 
352 Sang-bum Hong, Soon-do Hur, Sun-Mee Kim, Sungmin Hong, Ji-woong Chung, Namgoo Kang and Chang-Hee Kang

Table 1. Concentrations of ionic species in ice and firn core samples in various polar regions (unit of concentration: $\mu \mathrm{g} / \mathrm{L}$ )

\begin{tabular}{|c|c|c|c|c|c|c|c|c|}
\hline \multirow[b]{2}{*}{ Species } & \multicolumn{8}{|c|}{ References } \\
\hline & $\begin{array}{l}\text { Rothlisberger } \\
\text { et al., } 2000^{5}\end{array}$ & $\begin{array}{c}\text { Ivask } \\
\text { et al., } 2001^{6}\end{array}$ & $\begin{array}{l}\text { Cole-Dai., } \\
\text { et al., } 2006^{7}\end{array}$ & $\begin{array}{c}\text { Jauhiainen } \\
\text { et al., } 1999^{8}\end{array}$ & $\begin{array}{c}\text { Osterberg } \\
\text { et al., } 2006^{9}\end{array}$ & $\begin{array}{c}\text { Oliver } \\
\text { et al., } 2003^{4}\end{array}$ & $\begin{array}{l}\text { Eichler, } \\
2000^{10}\end{array}$ & $\begin{array}{c}\text { Kreutz } \\
\text { et al., } 2001^{11}\end{array}$ \\
\hline $\mathrm{Na}^{+}$ & $0^{\mathrm{a}}-100^{\mathrm{b}}$ & $51-891\left(207^{c}\right)$ & $1-50$ & $9-489(115)$ & $1-144(214)$ & $23.0^{\mathrm{d}}$ & $23.0^{\mathrm{d}}$ & $250.7^{\mathrm{d}}$ \\
\hline $\mathrm{NH}_{4}^{+}$ & $0-5$ & $15-297(93)$ & $1-5$ & $<$ DL-117(21) & & 205.2 & 102.6 & 174.6 \\
\hline $\mathrm{K}^{+}$ & & $13-343(72)$ & $0-10$ & $<$ DL-22.5(3.1) & $0.030-31.1(2.8)$ & 15.6 & 11.7 & 35.2 \\
\hline $\mathrm{Mg}^{2+}$ & & $29-408(137)$ & $0-20$ & $<$ DL-71(9.6) & $0.43-323(9.3)$ & 19.4 & 14.6 & 57.1 \\
\hline $\mathrm{Ca}^{2+}$ & $0-20$ & $61-608(411)$ & $1-50$ & $<$ DL-299(21.6) & $1.3-1465(81.4)$ & 188.4 & 182.4 & 1326.6 \\
\hline \multicolumn{9}{|l|}{$\mathrm{CH}_{3} \mathrm{CO}_{2}^{-}$} \\
\hline $\mathrm{HCO}_{2}^{-}$ & & & & $<$DL-51.1(7.9) & & 207.0 & 58.5 & \\
\hline MSA & & & & $<$ DL-51.1(5.6) & $1.7-7.6(4.1)$ & & & \\
\hline $\mathrm{Cl}^{-}$ & & $32-452(307)$ & $1-50$ & $18-1145(204)$ & $1.04-252(39.7)$ & 31.9 & 42.5 & 343.9 \\
\hline $\mathrm{SO}_{4}^{2-}$ & $0-800$ & $61-451(242)$ & $1-200$ & $8-855(193)$ & $12.1-985(97.4)$ & 528.3 & 533.1 & 648.4 \\
\hline $\mathrm{NO}_{3}^{-}$ & $0-60$ & $38-82(72)$ & $10-300$ & $4-394(71)$ & $33.2-211(77.2)$ & 266.6 & 204.6 & 341.0 \\
\hline $\mathrm{C}_{2} \mathrm{O}_{4}{ }^{2-}$ & & & & & & 17.6 & 8.8 & \\
\hline Site & Dome $\mathrm{C}$ & Dome B & Antarctica & $\begin{array}{c}\text { Svalbard, } \\
\text { Lomonosovfonna }\end{array}$ & Greenland & $\begin{array}{c}\text { Altai, } \\
\text { Belukha }\end{array}$ & $\begin{array}{l}\text { Swiss } \\
\text { Alps }\end{array}$ & $\begin{array}{l}\text { Tien Shan, } \\
\text { Inilcheck }\end{array}$ \\
\hline Altitude & $3233 \mathrm{~m}$ & $3809 \mathrm{~m}$ & & $1255 \mathrm{~m}$ & $3233 \mathrm{~m}$ & $4062 \mathrm{~m}$ & $4200 \mathrm{~m}$ & $5100 \mathrm{~m}$ \\
\hline $\begin{array}{l}\text { latitude, } \\
\text { longitude }\end{array}$ & $\begin{array}{l}75.06^{\circ} \mathrm{S}, \\
123.23^{\circ} \mathrm{E}\end{array}$ & $\begin{array}{l}79.00^{\circ} \mathrm{S}, \\
93.60^{\circ} \mathrm{E}\end{array}$ & & $\begin{array}{l}78^{\circ} 51^{\prime} \mathrm{N} \\
17^{\circ} 25^{\prime} \mathrm{E}\end{array}$ & $\begin{array}{l}73^{\circ} 58^{\prime} \mathrm{N} \\
38^{\circ} 40^{\prime} \mathrm{W}\end{array}$ & $\begin{array}{l}49^{\circ} 28^{\prime} \mathrm{N} \\
86^{\circ} 34^{\prime} \mathrm{E}\end{array}$ & $\begin{array}{l}45^{\circ} 55^{\prime} \mathrm{N} \\
07^{\circ} 52^{\prime} \mathrm{E}\end{array}$ & $\begin{array}{l}43^{\circ} \mathrm{N}, \\
79^{\circ} \mathrm{E}\end{array}$ \\
\hline
\end{tabular}

${ }^{\mathrm{a}}$ Minimum, ${ }^{\mathrm{b}}$ Maximum, ${ }^{\mathrm{c}}$ Mean, ${ }^{\mathrm{d}}$ Median

Table 2. Concentrations of ionic species in snow samples of various polar regions (unit of concentration: $\mu \mathrm{g} / \mathrm{L}$ )

\begin{tabular}{|c|c|c|c|c|c|c|c|c|c|}
\hline \multirow[b]{2}{*}{ Species } & \multicolumn{9}{|c|}{ References } \\
\hline & \multicolumn{3}{|c|}{$\begin{array}{c}\text { Mayweski and } \\
\text { Whitlow }^{12}\end{array}$} & \multirow{2}{*}{$\begin{array}{c}\text { Whitlow et al., } \\
1992^{13} \\
4.8\end{array}$} & \multicolumn{2}{|c|}{ ITASE $^{14}$} & \multirow{2}{*}{$\begin{array}{c}\text { Whitlow et al., } \\
1992^{13} \\
11.1\end{array}$} & \multirow{2}{*}{$\begin{array}{c}\text { National Climatic } \\
\text { Data Center }^{15}\end{array}$} & \multirow{2}{*}{$\begin{array}{c}\text { Kang et al., } \\
2004^{16} \\
12.4-17.3\end{array}$} \\
\hline $\mathrm{Na}^{+}$ & $12.6^{\mathrm{a}}$ & 7.2 & 9.5 & & 23 & 15.8 & & & \\
\hline $\mathrm{NH}_{4}^{+}$ & 7.4 & 10.0 & 15.2 & 9.1 & & & 1.2 & & $1.4-25.4$ \\
\hline $\mathrm{K}^{+}$ & 2.1 & 1.9 & 2.4 & 1.1 & 3.1 & & 1.1 & & 9.4-18.0 \\
\hline $\mathrm{Mg}^{2+}$ & 2.4 & 1.3 & 1.4 & 1.4 & 2.2 & 2.0 & 2.8 & 1.6 & $2.6-6.0$ \\
\hline $\mathrm{Ca}^{2+}$ & 7.4 & 12.6 & 12.2 & 9.9 & 3.5 & & 4.2 & 0.9 & $55.9-165.5$ \\
\hline MSA & & & & & & & & 6.8 & \\
\hline $\mathrm{Cl}^{-}$ & 32.9 & 19.9 & 25.1 & 16.9 & 43.7 & 36.1 & 34.1 & 33.6 & $19.5-45.7$ \\
\hline $\mathrm{SO}_{4}{ }^{2-}$ & 98.3 & 114.6 & 124.3 & 103.0 & 41.0 & 110.3 & 98.8 & 62.4 & $11.2-84.9$ \\
\hline $\mathrm{NO}_{3}^{-}$ & 88.7 & 86.3 & 83.6 & 124.3 & 36.1 & 80.2 & 62.2 & 57.1 & $33.1-38.4$ \\
\hline \multirow[b]{2}{*}{ Site } & \multicolumn{4}{|c|}{ Greenland } & \multicolumn{4}{|c|}{ Antarctica } & Alpine \\
\hline & SP1 & SP5 & SP7 & Summit & $00-1$ & $99-1$ & South Pole & $\begin{array}{l}\text { Dronning } \\
\text { maud land }\end{array}$ & $\begin{array}{c}\text { East Rongbuk } \\
\text { Glacier }\end{array}$ \\
\hline Depth (m) & $6 \mathrm{~m}$ & $4 \mathrm{~m}$ & $4.2 \mathrm{~m}$ & $6 \mathrm{~m}$ & $3 \mathrm{~m}$ & $3 \mathrm{~m}$ & $6 \mathrm{~m}$ & $3 \mathrm{~m}$ & $0.55-3.6 \mathrm{~m}$ \\
\hline $\begin{array}{l}\text { latitude, } \\
\text { longitude }\end{array}$ & $\begin{array}{l}77^{\circ} 11^{\prime} \mathrm{N}, \\
60^{\circ} 43^{\prime} \mathrm{W}\end{array}$ & $\begin{array}{l}66^{\circ} 57^{\prime} \mathrm{N} \\
44^{\circ} 29^{\prime} \mathrm{W}\end{array}$ & $\begin{array}{l}64^{\circ} 46^{\prime} \mathrm{N} \\
44^{\circ} 07^{\prime} \mathrm{W}\end{array}$ & $\begin{array}{l}72^{\circ} 34^{\prime} \mathrm{N}, \\
38^{\circ} 27^{\prime} \mathrm{W}\end{array}$ & $\begin{array}{r}79^{\circ} 22^{\prime} \mathrm{S} \\
111^{\circ} 13^{\prime}\end{array}$ & $\begin{array}{l}80^{\circ} 37^{\prime} \mathrm{S}, \\
122^{\circ} 36^{\prime} \mathrm{W}\end{array}$ & $\begin{array}{l}90^{\circ} \mathrm{S} \\
00^{\circ} \mathrm{E}\end{array}$ & $\begin{array}{l}75^{\circ} 00^{\prime} \mathrm{S} \\
00^{\circ} 04^{\prime} \mathrm{E}\end{array}$ & $\begin{array}{l}28^{\circ} 06^{\prime} \mathrm{N} \\
86^{\circ} 51^{\prime} \mathrm{E}\end{array}$ \\
\hline
\end{tabular}

과 빙하 시료는 시료채취가 쉽지 않으며 시료 부피가 비교적 제한적이고 분석시료의 개수가 많은 특징이 있다. 따라서 눈과 빙하의 이온성분들을 측정하기 위
해서는 이와 같은 시료의 특징을 고려한 측정법을 선 택하는 것이 중요하다. 지금까지 눈과 빙하의 이온성 분들의 측정은 이온크로마토그래피 시스템(IC)과 연 
속 흐름 분석법(Continuous Flow Analysis: CFA)을 주로 활용해왔다. 연속 흐름 분석법은 고분해도의 측 정 자료를 생산할 수 있는 장점이 있지만, 측정시스 템 운영이 쉽지 않고 일부 성분들 $\left(\mathrm{F}^{-}, \mathrm{NO}_{2}^{-}, \mathrm{Br}^{-}\right.$, $\mathrm{MSA}$, 유기 음이온 등)은 아직까지 $\mathrm{CFA}$ 측정 기술이 없는 실정이다. 그렇지만 이온크로마토그래피 시스템 은 비록 CFA법에 비해 측정 자료의 시간 분해도가 낮은 단점이 있지만 증류수의 관리, 실험실 환경, 분 석 조건(분석 칼럼, 용리액의 농도와 흐름 방식, 시료 주입량 등)에 따라 sub-ug/L 수준까지 검출할 수 있다. 더욱이 $\mathrm{CFA}$ 측정법에 의해 측정할 수 없는 $\mathrm{F}^{-}$, 유기 음이온 $\left(\mathrm{HCO}_{2}^{-}, \mathrm{CH}_{3} \mathrm{CO}_{2}^{-}\right), \mathrm{MSA}, \mathrm{Br}^{-}$성분들을 포함한 다양한 이온성분들을 동시에 측정할 수 있는 장점이 있다. ${ }^{17-18}$

본 연구의 목적은 이온크로마토그래피 시스템을 이용한 눈 시료 이온성분 측정법을 개선하고 측정자 료의 불확도 산출법을 개발하는 것이다. 극 지역 눈 시료의 이온성분을 측정하기 위해서는 실험과정에서 외부 오염물질의 영향을 최소화할 수 있는 실험 절차 를 수립하고 측정자료의 정도관리를 엄격하게 수행해 야 한다. 따라서 본 연구에서는 우선 측정자료의 정도 관리(Quality Assurance \& Quality Control)를 위해 분석 자료의 정확도(Accuracy), 재현성(Reproducibility), 검출 한계(Limit of Detection) 등을 조사하였다. 또한 실험 절차 가운데 시료 병 세척법을 검토하였으며 용융시 료에 필터를 적용할 경우의 오염영향 등을 조사하였 다. 마지막으로 North Greenland Eemian ice drilling (NEEM) 캠프의 풍상 지역에서 채취한 눈 시료의 이 온성분을 측정하고 실험과정에서 발생할 수 있는 오 차요인들을 조사하여 불확도(Uncertainty) 산출법을 제시 하였다. ${ }^{19}$ 측정자료는 측정법의 여러 과정에서 발생하는 다양한 오차요인에 의해 종합적으로 영향
을 받는다. 본 연구에서는 이온성분 가운데 $\mathrm{F}^{-}$성분 의 측정자료를 이용하여 다양한 오차요인들에 대한 불확도 및 이들의 합성을 통한 측정자료의 불확도 산 출법을 연구하였다.

\section{2. 연구방법}

\section{1. 눈 시료 채취 및 용융}

눈 시료는 그린란드 북서부 내륙 지역 NEEM 캠

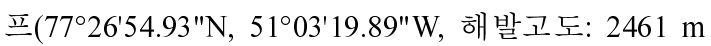
a.s.1.) 풍상 지역 약 $1 \mathrm{~km}$ 떨어진 지점에서 표면으로 부터 약 $3.5 \mathrm{~m}$ 깊이까지 $5 \mathrm{~cm}$ 간격으로 채취하였다. 눈 시료는 시료채취 과정에서 오염 가능성을 방지하 기 위해, 시료 채취자는 오염 방지복(TYVEK, Du Pont Limited-Use Protective Clothing)을 착용하였다. 눈 시료는 원형봉 형태로 제작한 시료 채취 관(외경: $5 \mathrm{~cm}$, 내경: $4.5 \mathrm{~cm}$, 길이: $30 \mathrm{~cm}$, 재질: 테프론)으로 채취하여 시료 병(Nalgene, $1 \mathrm{~L}, \mathrm{LDPE})$ 에 넣은 후 마 개로 닫고 비닐봉지를 이용하여 이중으로 포장하였 다. 시료 채취 관으로 채취한 시료 가운데 시료채취 지점의 첫 시료는 항상 취하지 않고, 이후 2,3 회째 채 취한 시료를 시료 병에 넣었다. 채취한 눈 시료는 현장 에서 $\sim-10{ }^{\circ} \mathrm{C}$ 조건으로 냉동 보관하였다. 수송과정에 서도 냉동 보관을 유지하여 이온성분의 분석 전까지 시료 용융을 방지하였다. 눈 시료 병은 극지연구소 빙 하 연구팀 청정실험실(청정도: Class 1000) 청정 벤치(청 정도: Class 10)로 옮겨 마개를 닫은 채 실온 $\left(20{ }^{\circ} \mathrm{C}\right)$ 에 서 약 2 3 hrs 정도 용융시킨 후 용융액 일부 $(\sim 5 \mathrm{~mL})$ 를 이온성분 분석용 시료 병(Wheaton, No. 986706)에 분취 후 이온성분 분석용 시료로 사용하였다.

\section{2. 눈 시료 이온성분 분석}

본 연구에서는 눈 시료 분석시간을 줄이고 최소 부

Table 3. Instrumental conditions for the analysis of ionic species

\begin{tabular}{lll}
\hline \hline & \multicolumn{1}{c}{ Anion analysis } & \multicolumn{1}{c}{ Cation analysis } \\
\hline System & ICS 2000 & ICS 2100 \\
Software & Chromelon 6.80 & Chromelon 6.80 \\
Column & IonPac AS $15(2 \times 250 \mathrm{~mm})$ & IonPac CS $12 \mathrm{~A}(4 \times 250 \mathrm{~mm})$ \\
Eluent & IonPac AG $15(2 \times 50 \mathrm{~mm})$ & IonPac CG $12 \mathrm{~A}(4 \times 50 \mathrm{~mm})$ \\
Suppressor & $6-55 \mathrm{mM} \mathrm{KOH}$ (gradient elution) & $20 \mathrm{mM} \mathrm{MSA} \mathrm{(isocratic} \mathrm{elution)}$ \\
Flow Rate & ASRS-300 & CSRS-300 \\
Injection Volume & $0.5 \mathrm{~mL} \mathrm{~min} \mathrm{~mL} \mathrm{~min}^{-1}$ & $1.0 \mathrm{~mL}$ \\
Background Conductivity & $200 \mu \mathrm{L}$ & $200 \mu \mathrm{L}$ \\
Background Pressure & $\sim 0.640 \mu \mathrm{S}$ & $\sim 0.065 \mu \mathrm{S}$ \\
\hline
\end{tabular}

Vol. 25, No. 6, 2012 
354 Sang-bum Hong, Soon-do Hur, Sun-Mee Kim, Sungmin Hong, Ji-woong Chung, Namgoo Kang and Chang-Hee Kang

피로 음, 양이온을 동시에 측정할 수 있는 이온크로마토 그래피 시스템을 구성하여 운영하였다(Table 3). IC 시스 템은 청정분석실(청정도: Class 1000) Clean Booth(청정 도: Class 10) 내에 설치, 운영하여 실험실 실내 공기에 의한 오염 가능성을 최소화하였다. 또한 실험자는 청정 복(Woojin ACT, polyester 100\%)을 착용함으로써 실험자 에 의한 시료의 오염 가능성을 방지하였다. IC 시스템에 사용하는 증류수는 5분 동안 초음파 세척기(Cole-Parmer ultrasonic cleaner, Model: 8891-06)로 탈 가스화 (degassing)하여 용존 가스의 양을 최소화한 후 사용하 여 잡음(noise) 신호의 세기를 감소시키고자 하였다.

양이온 분석은 용리액의 농도가 일정한 isocratic 용리액 방법을, 음이온 분석은 시간에 따라 용리액의 농도가 변하는 gradient 용리액 방법을 이용하였으며 시료 주입량은 각각 $200 \mu \mathrm{L}$ 를 사용하였다. 분석 조 건 가운데 음이온 분석칼럼은 IonPac AS $15(2 \times 250$ $\mathrm{mm}$ )를 사용하여 $\mathrm{Na}_{2} \mathrm{CO}_{3} / \mathrm{NaHCO}_{3}$ 용리액 대신 $\mathrm{KOH}$ 용리액을 사용하였다. 분석칼럼 충진제 규격(직경 : 2 $\mathrm{mm}$ )은 측정 성분들의 피크 분해도(resolution)를 증가 시키기 위해 선정하였다. $\mathrm{KOH}$ 용리액 방법은 바탕 전도도를 $<1 u S$ 으로 낮출 수 있기 때문에 미량 음이 온 성분 분석에 유리한 것으로 나타났다. 그렇지만 $\mathrm{Na}_{2} \mathrm{CO}_{3} / \mathrm{NaHCO}_{3}$ 용리액 방법으로는 검출되지 않는 $\mathrm{CO}_{3}{ }^{2-}$ 가 측정되기 때문에 $\mathrm{SO}_{4}{ }^{2-}$ 의 정량에 방해 효과 를 줄 수 있는 단점이 있다. 실제 시료의 이온성분 측정은 분석 전에 양이온은 $\sim 5 \mathrm{hr}$, 음이온은 $\sim 12 \mathrm{hr}$
정도 용리액을 흘린 후 시스템의 바탕신호를 조사하 고 시스템과 증류수 바탕시료 주입결과를 확인하여 수행하였다. Fig. 1은 각각 음이온과 양이온 표준 용 액의 크로마토그램을 제시한 것이다. 양이온은 모든 성분들의 피크 분해도가 $~ 1.2$ 이상이며 특히 비슷한 시간대에 검출되는 $\mathrm{Li}^{+}$와 $\mathrm{Na}^{+}, \mathrm{Na}^{+}$와 $\mathrm{NH}_{4}{ }^{+}$의 경우 각각 피크 분해도가 $\sim 1.4, \sim 1.2$ 로 조사되었다. 음이온 은 gradient 용리액 방법임에도 바탕선의 전도도 증가 가 크지 않은 것을 알 수 있다. 피크 분해도는 $\mathrm{CH}_{3} \mathrm{CO}_{2}{ }^{-}$와 $\mathrm{HCO}_{2}{ }^{-}, \mathrm{CO}_{3}{ }^{2-}$ 와 $\mathrm{SO}_{4}{ }^{2-}, \mathrm{SO}_{4}{ }^{2-}$ 와 $\mathrm{Br}^{-}$가 각 각 $\sim 1.3, \sim 1.4, \sim 1.2$ 로 조사되었고 나머지 성분들의 피크 분해도는 1.5 이상으로 나타났다.

\section{3. 표준용액}

검정곡선(Calibration Curve) 작성을 위한 표준용액 은 Dionex사의 양이온(Product \#046070)과 음이온 (Product \#57590) 표준용액을 증류수로 희석하여 사 용하였다. 유기산과 $\mathrm{MSA}$ 성분은 각각 $\mathrm{CH}_{3} \mathrm{CO}_{2} \mathrm{Na}$ ( $>99.99 \%$ 이상, Fluka), $\mathrm{HCO}_{2} \mathrm{Na}(>99 \%$, Fluka), MSANa (98\%, Sigma Aldrich) 고체 시약을 이용하여 $10 \mathrm{ppmm}$ 이상의 고농도 표준용액을 조제한 후 사용하였다. Dionex사의 표준시약은 이온성분의 안정성을 고려하 여 냉장 보관하였고 인증서(certificate)상의 사용만기 일을 준수하였다. 유기산과 MSA성분의 경우 대략 3 개월 정도 간격으로 조제하였고 저장용액을 냉동 보 관 후 시료 분석 시 용융하여 증류수로 희석 후 사용
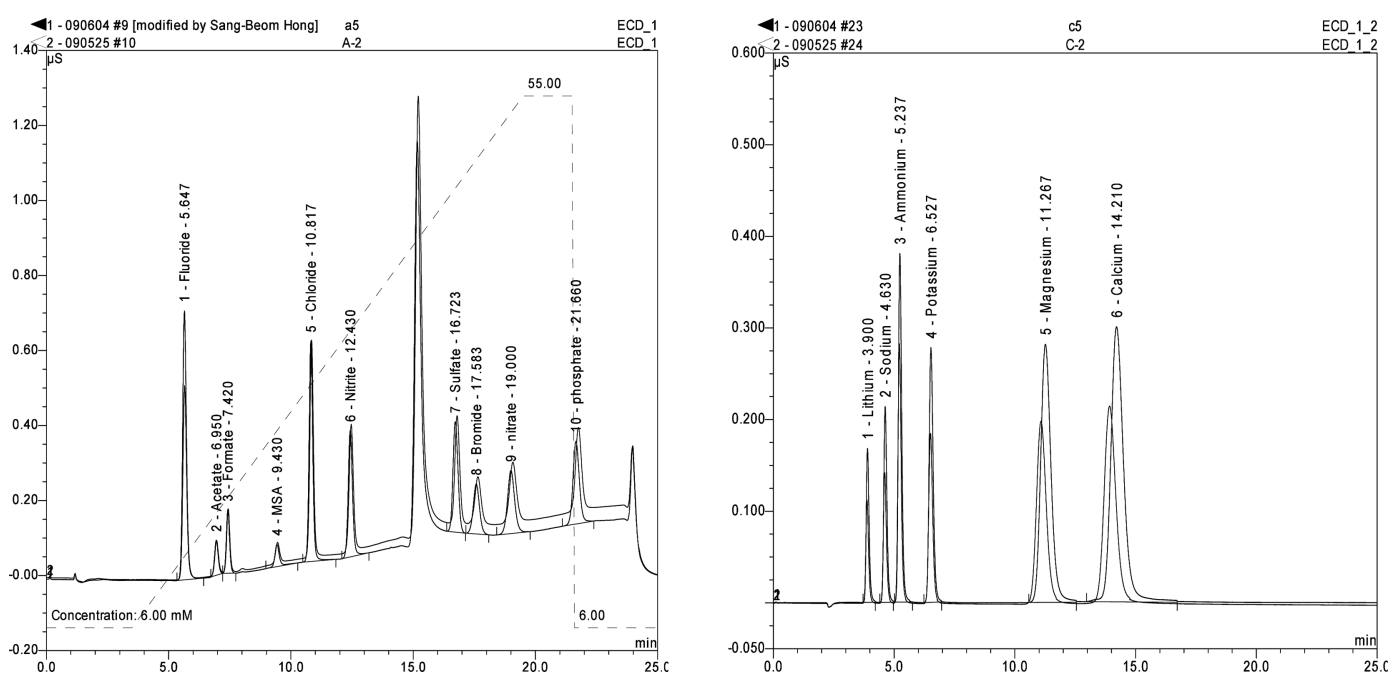

Fig. 1. Chromatograms of cations and anions in standard solutions $\left(\mathrm{F}^{-}\right.$(12.1); $\mathrm{CH}_{3} \mathrm{CO}_{2}^{-}$(7.7); $\mathrm{HCO}_{2}^{-}$(7.7); $\mathrm{MSA}^{-}(7.7) ; \mathrm{Cl}^{-}$ (22.4); $\mathrm{NO}_{2}^{-}$(22.4); $\mathrm{SO}_{4}{ }^{2-}$ (22.4); $\mathrm{Br}^{-}(22.4) ; \mathrm{NO}_{3}^{-}$(22.4); $\mathrm{PO}_{4}{ }^{2-}$ (44.8); $\mathrm{Li}^{+}$(3.3); $\mathrm{Na}^{+}$(13.3); $\mathrm{NH}_{4}^{+}$(16.7); $\mathrm{K}^{+}$(33.4); $\mathrm{Mg}^{2+}(16.7) ; \mathrm{Ca}^{2+}(33.4)$, unit of concentration: $\left.\mu \mathrm{g} / \mathrm{L}\right)$. 
하였다. 교정용 표준용액은 주사기(Hamilton, Gastight 1005)와 용량 플라스크(Pyrex, No. 5640)를 이용하여 부피비 희석법으로 조제 하였다. 검정곡선 작성용 표 준용액을 조제할 때 사용한 증류수는 표준용액과 함께 분석한 후 증류수의 이온성분에 의한 피크의 면적을 제외한 후 검정곡선을 작성하였다. 수용액의 미량 이 온성분들을 정량 분석하기 위해서는 증류수(바탕시료) 의 이온성분들이 거의 검출되지 않아야 하므로 증류수 $(>18.2 \mathrm{M} \Omega \cdot \mathrm{cm})$ 의 유지, 관리가 매우 중요하다.

\section{4. 실험 도구의 세척 및 관리}

극 지역 눈 시료의 미량 이온성분을 측정하기 위해 서는 눈 시료 채취에 사용하는 도구(시료 병과 채취 도구)의 세척, 보관법이 중요하다. 시료 채취 도구들 (눈 삽, 채취 봉, 시료 병 등)은 극지연구소 빙하연구 팀 청정실험실의 산 세척법으로 세척, 보관 $(0.1 \%$ $\mathrm{HNO}_{3}$ ) 후 사용하기 전에 증류수(Milli Q)를 이용하 여 다시 3 회 공세척후 사용하였다. ${ }^{20}$ 세척이 끝난 도 구들은 건조 후 비닐봉지로 이중 포장하여 현장까지 수송하였다. 눈 시료를 용융시킨 후 용융액의 일부를 분취, 보관하는 이온성분 분석용 시료 병과 IC 시스 템의 시료 자동주입기(auto-injector)의 병과 마개들은 증류수로 세척하였다. 이들은 구입 후 1차 증류수로 공세척한 후 최소 $24 \mathrm{hr}$ 동안 증류수(Milli Q)로 침 적(leaching)시킨 다음 증류수(Milli Q)를 채워 약 1 $\mathrm{hr}$ 정도 초음파 세척기로 세척하였다. 마지막으로 증
류수(Milli Q)를 이용하여 3차례 공세척한 후 청정분 석실의 clean bench(청정도: Class 10)에서 건조 후, 마개를 닫고 증류수(Milli Q)로 세척된 비닐봉지에 넣어 포장 후 실온에서 보관하였다.

\section{5. 필터 시험}

눈과 빙하의 용융액은 불용성 입자들을 포함하고 있기 때문에 IC 시스템을 이용하여 지속해서 분석하 면 분석칼럼의 분리효율에 영향을 미칠 수 있다. 따 라서 이온성분의 분석오차를 줄이기 위해서는 시료 를 주입하기 전에 필터를 이용하여 불용성 입자를 제 거하는 과정이 필요하다.

그렇지만 시료 용융액이 필터를 통과하여 여과될 때 필터로부터 이온성분이 용출되면 용융액 이온성분의 측정 결과는 이들에 의해 양의 방해 효과(positive interference)를 받을 수 있다. 본 연구에서는 수용액의 불용성 물질 제거를 위해 주로 사용하는 대표적인 필 터(Nylon: StarFil, SFNY 1345, MCM: mixed cellulose (acetate and nitrate), PTFE-Ion: Millipore, IC Millex Filter Units)를 대상으로 증류수를 흘려준 후 용출액 의 이온성분들의 농도를 측정함으로써 필터 자체의 용출특성과 필터의 세척 조건을 조사하였다.

\section{6. 불확도 계산}

눈 시료 이온성분 측정자료의 불확도를 추정하기 위해 NEEM 캠프에서 채취한 눈 시료에서 측정된

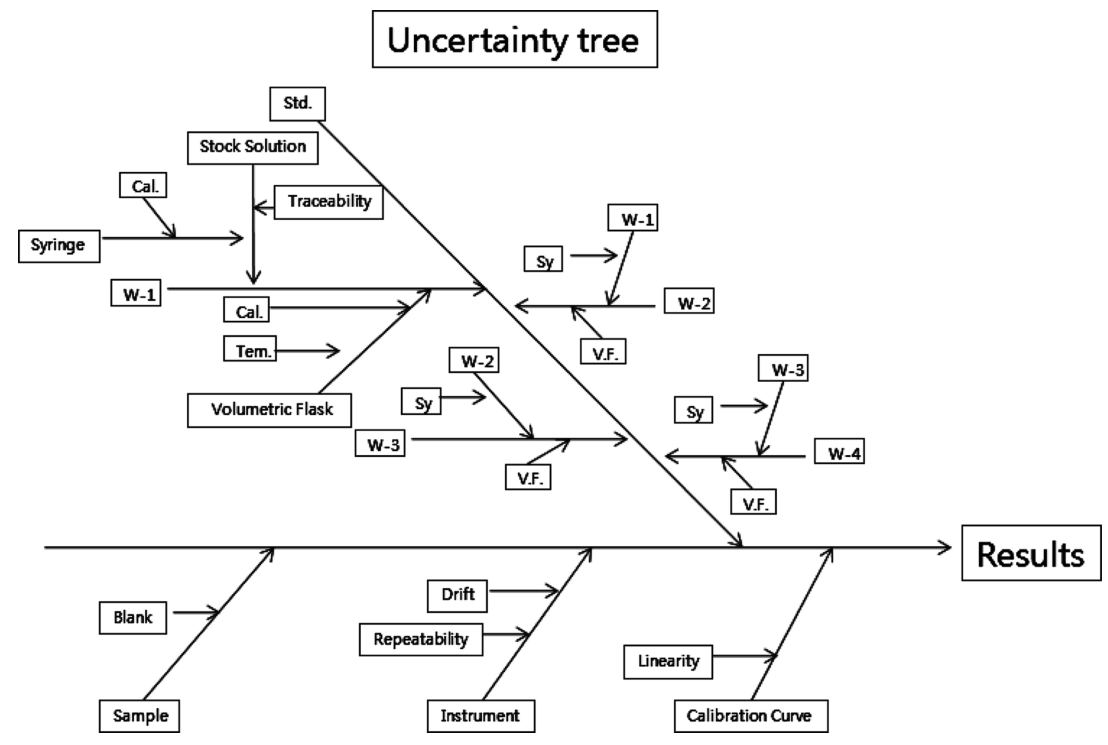

Fig. 2. Uncertainty tree for determination of uncertainties of ionic species in snowpit sample.

Vol. 25, No. 6, 2012 
356 Sang-bum Hong, Soon-do Hur, Sun-Mee Kim, Sungmin Hong, Ji-woong Chung, Namgoo Kang and Chang-Hee Kang

이온성분 가운데 $\mathrm{F}^{-}$성분에 대해 시험적으로 적용하 였다. 이를 위해 불확도에 관계된 여러 문헌을 검토 하여 제시한 여러 요인 가운데 중요 요소들을 재선정 하여 농도 산출 관계식을 설정하고 식 (1)에 포함된 요인들을 Fig. 2에 도식화 하였다. ${ }^{1921}$

$C_{i}=X_{i} \times f_{1} \times f_{2} \times f_{3}$

$\mathrm{C}_{i}$ : 눈 시료의 이온성분의 농도

$\mathrm{X}_{i}$ : 검정곡선을 이용한 농도 측정 값 $\left(\frac{[\mathrm{y}-(\mathrm{i}-\mathrm{blank})]}{\mathrm{s}}\right.$, $i$ : 검정곡선의 절편, $s$ : 검정곡선의 기울기 $)$

$f_{1}$ : 표준시료 희석과정에 의한 영향,

$f_{2}$ : 측정 시스템의 재현성에 의한 영향,

$f_{3}$ : 측정 시스템의 변동성에 의한 영향

\section{3. 결과 및 토의}

3.1. 분석방법 성능평가: 검정곡선 요소(농도범위, 회귀관계식, 결정계수, 추정치의 표준오차), 재현성, 정확도, 검출한계

Table 4는 검정곡선 작성용 표준용액의 농도범위에 따른 회귀관계식, 결정계수 $\left(\mathrm{r}^{2}\right), \mathrm{S} . \mathrm{E}$.를 정리한 것이다. 이온성분의 정량은 각 성분별 크로마토그램 신호의 면적을 사용하였다. 회귀관계식은 $\mathrm{NH}_{4}{ }^{+}$의 경우 이차 식을 사용하였으며 나머지 성분들은 일차식의 회귀 관계식으로 농도를 계산하였다. 조사 결과 모든 이온 성분들의 $\mathrm{r}^{2}$ 이 0.99 이상, S.E.는 0.02 미만으로 회귀 관계식을 이용한 예측의 신뢰도는 매우 우수한 것으
로 나타났다. ${ }^{17}$

측정시스템의 재현성(Reproducibility)을 조사하기 위해 시료의 이온성분 분석과 함께 표준용액을 농도 별로 수회(>3회) 연속 측정하였다(Table 5). 비교적 짧은 시간 동안의 측정시스템의 재현성을 조사하기 위 해 연속적으로 주입한 표준용액 측정결과의 $\mathrm{RSD}(\%)$ 를 계산하였다. 검정곡선 작성용 표준용액의 농도 범 위에서 양이온 성분들은 $\mathrm{Na}^{+}, \mathrm{NH}_{4}^{+}, \mathrm{K}^{+}, \mathrm{Mg}^{2+}, \mathrm{Ca}^{2+}$ 이 각각 0.9-2.1, 0.6-3.4, 0.5-7.6, 0.5-17.4, 0.4-12.1\% 로 나타났다. 음이온의 경 우 $\mathrm{F}^{-}, \mathrm{CH}_{3} \mathrm{CO}_{2}^{-}, \mathrm{HCO}_{2}^{-}$, $\mathrm{MSA}, \mathrm{Cl}^{-}, \mathrm{NO}_{2}^{-}, \mathrm{SO}_{4}{ }^{2-}, \mathrm{Br}^{-}, \mathrm{NO}_{3}^{-}$이 각각 0.1-26.8, $0.1-27.6,0.1-10.7,0.2-20.8,0.2-24.7,0.4-19.4,0.3-$ $6.4,0.2-8.6,0.3-23.4 \%$ 로 조사되었다. 음, 양이온 성 분 모두 가장 낮은 표준용액의 농도 수준(standard level-1)에서 양이온과 음이온의 재현성이 각각 1.7$17.4 \%, 6.4-27.6 \%$ 로 가장 낮았다. 그렇지만 level-2부 터 level-6까지의 농도범위에서는 일부 성분을 제외하 고 $3 \%$ 미만으로 양호한 재현성을 유지하였다.

측정자료의 정확도(Accuracy)를 조사하기 위하여 인증물질 $\mathrm{BCR}^{\circledR}-408$ 을 분석한 후 인증 값(Certificate value)과 측정값 간의 상대오차를 계산하였다(Table 6). 양이온 성분들은 상대오차가 $\mathrm{Na}^{+}, \mathrm{NH}_{4}^{+}, \mathrm{K}^{+}, \mathrm{Mg}^{2+}$, $\mathrm{Ca}^{2+}$ 이 각각 $4.9,12.0,5.4,4.5,6.3 \%$ 로 조사되어 $\mathrm{NH}_{4}{ }^{+}$의 상대오차가 가장 높은 것으로 나타났다. 음이 온 성분들은 $\mathrm{SO}_{4}{ }^{2-}$ 의 상대오차가 $5.6 \%$ 로 가장 큰 값 을 보였으며 $\mathrm{NO}_{3}^{-}$와 $\mathrm{Cl}^{-}$는 각각 $1.3,2.2 \%$ 로 조사되었 다. 이러한 결과는 Jauhianinen 등(1999)과 Osterberg

Table 4. Calibration parameters (Concentration Range, Regression, $r^{2}$, S.E.)

\begin{tabular}{|c|c|c|c|c|c|}
\hline \multirow{2}{*}{ Species } & \multirow{2}{*}{$\begin{array}{c}\text { Con. Range } \\
\text { (ug/L) }\end{array}$} & \multicolumn{2}{|c|}{ Regression } & \multirow{2}{*}{$r^{2}$} & \multirow{2}{*}{ S.E. ${ }^{a}$} \\
\hline & & Slope & Intercept & & \\
\hline $\mathrm{Na}^{+}$ & $0.40-200.0$ & 0.0039 & -0.0011 & 0.9997 & 0.0071 \\
\hline $\mathrm{NH}_{4}^{+}$ & $0.50-250.0$ & $Y=-0.00000$ & $72 X+0.02048$ & 0.9997 & 0.0058 \\
\hline $\mathrm{K}^{+}$ & $1.00-500.0$ & 0.0025 & -0.0061 & 0.9997 & 0.0095 \\
\hline $\mathrm{Mg}^{2+}$ & $0.50-250.0$ & 0.0075 & -0.0001 & 1.000 & 0.0045 \\
\hline $\mathrm{Ca}^{2+}$ & $1.00-500.0$ & 0.005 & 0.0172 & 0.9999 & 0.0153 \\
\hline $\mathrm{F}^{-}$ & $0.10-50.5$ & 0.0078 & -0.0066 & 0.9987 & 0.0062 \\
\hline $\mathrm{CH}_{3} \mathrm{CO}_{2}^{-}$ & $0.49-247.4$ & 0.0016 & 0.0016 & 0.9996 & 0.0067 \\
\hline $\mathrm{HCO}_{2}^{-}$ & $0.49-245.5$ & 0.0031 & -0.0025 & 0.9995 & 0.0086 \\
\hline MSA & $0.50-249.2$ & 0.0020 & -0.0101 & 0.9975 & 0.0107 \\
\hline $\mathrm{Cl}^{-}$ & $0.51-252.5$ & 0.0043 & -0.0198 & 0.9981 & 0.0201 \\
\hline $\mathrm{NO}_{2}^{-}$ & $0.51-252.5$ & 0.003 & -0.0153 & 0.9974 & 0.0165 \\
\hline $\mathrm{SO}_{4}{ }^{2-}$ & $0.50-249.3$ & 0.0027 & -0.0124 & 0.9964 & 0.0173 \\
\hline $\mathrm{Br}^{-}$ & $0.50-250.0$ & 0.0014 & -0.0055 & 0.9981 & 0.0066 \\
\hline $\mathrm{NO}_{3}^{-}$ & $0.51-252.5$ & 0.0019 & -0.0071 & 0.9976 & 0.0107 \\
\hline
\end{tabular}

${ }^{a}$ S.E. indicates standard error of the estimate 
Table 5. Reproducibilities of ion chromatography system (unit of concentration: $\mu \mathrm{g} / \mathrm{L}$ )

\begin{tabular}{|c|c|c|c|c|c|c|}
\hline Species & Con. & $\mathrm{RSD}^{\mathrm{a}}(\%)$ & Con. & RSD (\%) & Con. & RSD (\%) \\
\hline $\mathrm{Na}^{+}$ & 0.40 & 2.1 & 4.00 & 2.0 & 20.0 & 1.7 \\
\hline $\mathrm{NH}_{4}^{+}$ & 0.50 & 1.7 & 5.00 & 1.3 & 25.0 & 1.8 \\
\hline $\mathrm{K}^{+}$ & 1.00 & 7.6 & 10.00 & 0.5 & 50.0 & 1.9 \\
\hline $\mathrm{Mg}^{2+}$ & 0.50 & 17.4 & 5.00 & 2.1 & 25.0 & 1.2 \\
\hline $\mathrm{Ca}^{2+}$ & 1.00 & 12.1 & 10.00 & 9.0 & 50.0 & 0.5 \\
\hline $\mathrm{F}^{-}$ & 0.10 & 26.8 & 1.01 & 1.5 & 5.05 & 0.3 \\
\hline $\mathrm{CH}_{3} \mathrm{CO}_{2}^{-}$ & 0.49 & 27.6 & 4.95 & 0.5 & 24.74 & 0.7 \\
\hline $\mathrm{HCO}_{2}^{-}$ & 0.49 & 10.7 & 4.91 & 1.3 & 24.55 & 0.7 \\
\hline MSA & 0.50 & 20.8 & 4.98 & 0.5 & 24.92 & 0.2 \\
\hline $\mathrm{Cl}^{-}$ & 0.51 & 24.7 & 5.05 & 0.4 & 25.25 & 0.3 \\
\hline $\mathrm{NO}_{2}^{-}$ & 0.51 & 19.4 & 5.05 & 1.0 & 25.25 & 0.2 \\
\hline $\mathrm{SO}_{4}{ }^{2-}$ & 0.50 & 6.4 & 4.99 & 1.4 & 24.93 & 0.5 \\
\hline $\mathrm{Br}^{-}$ & 0.50 & 8.6 & 5.00 & 5.9 & 25.00 & 3.1 \\
\hline \multirow[t]{2}{*}{$\mathrm{NO}_{3}^{-}$} & 0.51 & 23.4 & 5.05 & 7.2 & 25.25 & 1.0 \\
\hline & Con. & RSD (\%) & Con. & RSD (\%) & Con. & RSD (\%) \\
\hline $\mathrm{Na}^{+}$ & 40.0 & 1.9 & 100.0 & 0.9 & 200.0 & 1.5 \\
\hline $\mathrm{NH}_{4}^{+}$ & 50.0 & 1.0 & 125.0 & 0.6 & 250.0 & 3.4 \\
\hline $\mathrm{K}^{+}$ & 100.0 & 1.3 & 250.0 & 0.8 & 500.0 & 1.5 \\
\hline $\mathrm{Mg}^{2+}$ & 50.0 & 0.5 & 125.0 & 0.8 & 250.0 & 1.4 \\
\hline $\mathrm{Ca}^{2+}$ & 100.0 & 0.4 & 250.0 & 0.9 & 500.0 & 1.3 \\
\hline $\mathrm{F}^{-}$ & 10.1 & 0.3 & 20.2 & 0.5 & 50.5 & 0.1 \\
\hline $\mathrm{CH}_{3} \mathrm{CO}_{2}^{-}$ & 49.5 & 0.4 & 99.0 & 0.4 & 247.4 & 0.1 \\
\hline $\mathrm{HCO}_{2}^{-}$ & 49.1 & 0.6 & 98.2 & 0.4 & 245.5 & 0.1 \\
\hline MSA & 49.8 & 0.6 & 99.7 & 0.4 & 249.2 & 0.2 \\
\hline $\mathrm{Cl}^{-}$ & 50.0 & 0.2 & 101.0 & 0.3 & 252.5 & 0.2 \\
\hline $\mathrm{NO}_{2}^{-}$ & 50.5 & 0.4 & 101.0 & 0.4 & 252.5 & 1.7 \\
\hline $\mathrm{SO}_{4}{ }^{2-}$ & 49.9 & 0.3 & 99.7 & 0.3 & 249.3 & 0.3 \\
\hline $\mathrm{Br}^{-}$ & 50.0 & 0.2 & 100.0 & 2.7 & 250.0 & 1.2 \\
\hline $\mathrm{NO}_{3}^{-}$ & 50.5 & 0.9 & 101.0 & 0.8 & 252.5 & 0.3 \\
\hline
\end{tabular}

a Standard deviation/Mean $\times 100(\%)$ of 3 replicates of multi-level working standards. R.S.D. indicates variability of measurement result at the same replicated measurement condition over a short time period.

Table 6. Results for the accuracy test of anions and cations in diluted reference solutions (BCR $\left.{ }^{\circledR}-408\right)$ (unit of concentration: $\mu \mathrm{g} / \mathrm{L}$ )

\begin{tabular}{|c|c|c|c|c|c|c|c|c|}
\hline \multirow{2}{*}{ Species } & \multicolumn{3}{|c|}{ This study ${ }^{\mathrm{a}}$} & \multicolumn{2}{|c|}{ "Jauhianinen et al., $1999^{8}$} & \multicolumn{3}{|c|}{ Osterberg et al., $2006^{9}$} \\
\hline & C.V. & M.V. & R.E & C.V. & R.E & C.V. & M.V. & R.E \\
\hline $\mathrm{Na}^{+}$ & $96.6 \pm 1.4$ & $101.3 \pm 2.2$ & -4.9 & 10.05 & 10.0 & 19.3 & 20.2 & -4.7 \\
\hline $\mathrm{NH}_{4}^{+}$ & $37.9 \pm 3.6$ & $33.3 \pm 0.8$ & 12.0 & 20 & 7.8 & & & \\
\hline $\mathrm{K}^{+}$ & $9.0 \pm 1.2$ & $9.5 \pm 1.1$ & -5.4 & 10.1 & 2.5 & 0.9 & 1.1 & -22.2 \\
\hline $\mathrm{Mg}^{2+}$ & $14.9 \pm 0.3$ & $15.6 \pm 0.8$ & -4.5 & 10.1 & 5.0 & 9.6 & 10.7 & -11.5 \\
\hline $\mathrm{Ca}^{2+}$ & $30.8 \pm 0.4$ & $28.8 \pm 1.8$ & 6.3 & 50.3 & 1.7 & 42.8 & 44.4 & -3.7 \\
\hline $\mathrm{Cl}^{-}$ & $238.6 \pm 2.5$ & $233.4 \pm 2.7$ & 2.2 & 30.5 & -5.2 & 105.5 & 106 & -0.5 \\
\hline $\mathrm{SO}_{4}^{2-}$ & $100.9 \pm 2.9$ & $106.6 \pm 2.5$ & -5.6 & 151 & 3.0 & 37 & 37.8 & -2.2 \\
\hline $\mathrm{NO}_{3}^{-}$ & $124.6 \pm 1.7$ & $122.9 \pm 1.7$ & 1.3 & 101 & -1.3 & & & \\
\hline
\end{tabular}

${ }^{\mathrm{a} C R M}$ was tested after diluting $\mathrm{BCR}^{\circledR}-408(1: 1000)$

등(2006)의 연구 결과와 유사한 수준이다. ${ }^{8-9}$

측정시스템의 검출한계(Limit of Detection)는 시료 분석 기간 측정한 바탕시료(증류수)의 측정 결과(9회)
를 이용하였다. 그리고 student t 분포를 사용해 $95 \%$ 신뢰 수준의 구간에서 실제 측정시스템의 검출한계 를 밝히고자 하였다(Table 7). 양이온 성분의 경우

Vol. 25, No. 6, 2012 
358 Sang-bum Hong, Soon-do Hur, Sun-Mee Kim, Sungmin Hong, Ji-woong Chung, Namgoo Kang and Chang-Hee Kang

Table 7. Intercomparison of performances of IC system (unit of concentration: $\mu \mathrm{g} / \mathrm{L}$ )

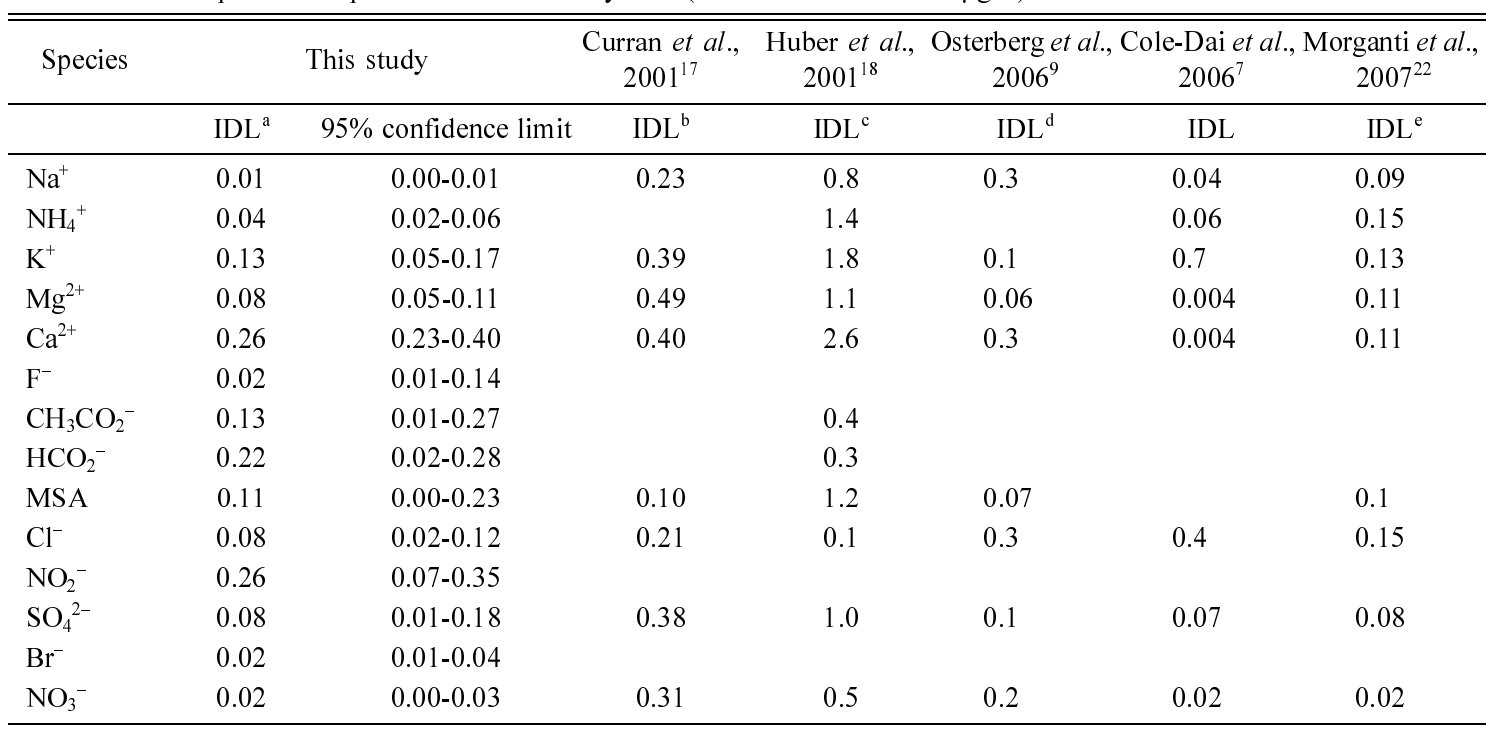

aDL was calculated by $3 \mathrm{~s}$ of 10 DI water samples and $95 \%$ confidence limit was calculated by student $t$ distribution

${ }^{b}$ IDL was defined as the amount of solute producing a signal-to-noise ratio of 3 (Errors given correspond to 1s)

${ }^{\mathrm{C}} \mathrm{IDL}$ was defined as the amount of solute producing a signal-to-noise ratio of 3 (Errors given correspond to 1s)

dIDL was calculated by $3 \mathrm{~s}$ of 10 DI water samples

${ }^{\mathrm{e}} \mathrm{IDL}$ was calculated as three times the standard deviation of 10 replicate of a $1 \mu \mathrm{g} \mathrm{L}^{-1}\left(\mathrm{Na}^{+}, \mathrm{NH}_{4}^{+}, \mathrm{K}^{+}, \mathrm{Mg}^{2+}, \mathrm{Ca}^{2+}, \mathrm{MSA}^{2}, 2 \mu \mathrm{g} \mathrm{L}-1\right.$ $\left(\mathrm{Cl}^{-}, \mathrm{NO}_{3}^{-}, \mathrm{SO}_{4}{ }^{2-}\right)$ standard solution

$0.01 \sim 0.26 \mu \mathrm{g} / \mathrm{L}$ 로 조사되었는데 $\mathrm{Ca}^{2+}$ 이 $0.26 \mu \mathrm{g} / \mathrm{L}$ 로 가장 높은 것으로 나타났다. 양이온 성분 가운데 오 염 가능성이 비교적 높은 $\mathrm{Na}^{+}$와 $\mathrm{NH}_{4}^{+}$의 $\mathrm{LOD}$ 는 각 각 $0.01,0.04 \mu \mathrm{g} / \mathrm{L}$ 로서 실험실 환경과 실험자에 의 한 오염 영향이 미미한 수준으로 조사되었다. 음이온 성분들은 $0.02 \sim 0.26 \mu \mathrm{g} / \mathrm{L}$ 로 선행연구 결과와 유사하 며 특히 실험실 환경에 민감한 $\mathrm{CH}_{3} \mathrm{CO}_{2}^{-}, \mathrm{HCO}_{2}^{-}$은 $0.13,0.22 \mu \mathrm{g} / \mathrm{L}$ 로 나타났다.

\section{2. 시료 병의 세척방법}

시료 병과 시료채취 도구들의 청정도(Cleanliness) 는 눈 시료의 이온성분 측정농도에 영향을 줄 수 있 다. 본 연구에서는 시료 병에 대한 실험실 바탕시험 (Lab blank test)을 통해 시료 병의 세척 및 관리법을 검토하였다. 우선 이온분석용 시료 병(Wheaton, No. 986706)에 의한 오염영향을 조사하기 위해 시료 병 $(\mathrm{n}=5)$ 에 증류수 $(\sim 5 \mathrm{~mL})$ 를 넣어 $\sim 1 \mathrm{hr}$ 동안 용출시킨 후 이온성분을 측정하였다. 측정 결과 양이온 성분 가운데 $\mathrm{NH}_{4}{ }^{+}$이 $0.9 \pm 0.1$ (평균표준편차) $\mu \mathrm{g} / \mathrm{L}$, 음이온 성분 가운데 $\mathrm{CH}_{3} \mathrm{CO}_{2}^{-}, \mathrm{HCO}_{2}^{-}, \mathrm{Cl}^{-}, \mathrm{NO}_{2}^{-}, \mathrm{NO}_{3}^{-}$이 각각 $0.4 \pm 0.2,0.3 \pm 0.1,0.6 \pm 0.1,0.4 \pm 0.2,1.2 \pm 0.6 \mu \mathrm{g} / \mathrm{L}$
로 나타났다. 눈 시료 채취 시료 병(Nalgene, $1 \mathrm{~L}$, $\mathrm{LDPE}$ )의 실험실 바탕시험은 그린란드 NEEM 캠프 에서 사용한 시료 병과 동일한 방법으로 세척한 시료 병을 이용하였다. 실제 눈 시료 용융액 부피( 300 $\mathrm{mL})$ 의 증류수를 넣어 $2-3 \mathrm{hr}$ 정도 실온에서 용출시킨 후 이온성분을 측정하였다. 조사 결과 $\mathrm{CH}_{3} \mathrm{CO}_{2}^{-}$, $\mathrm{HCO}_{2}^{-}, \mathrm{NO}_{2}^{-}, \mathrm{NO}_{3}^{-}, \mathrm{NH}_{4}^{+}$성분들이 각각 $179.8 \pm 21.7$, $166.5 \pm 22.8,10.1 \pm 2.2,120.2 \pm 10.6,9.0 \pm 7.8 \mu \mathrm{g} / \mathrm{L}$ 로 측 정되었고 나머지 성분들은 모두 검출한계 이하로 나 타났다.

실험실 바탕시험 결과 현장 시료채취용 시료 병이 이온분석용 시료 병에 비해 눈 시료 이온성분의 측정 농도에 미치는 오염영향이 비교적 크다는 것을 보여 주고 있다. 그리고 측정된 이온성분들은 두 종류의 시료 병에서 대체로 비슷한 것으로 나타나 이들 성분 들이 다른 성분들에 비해 시료 병에 의한 오염 가능 성이 높은 것을 알 수 있다. 이러한 연구 결과는 Siggaard-Andersen 등(2002)이 제안한 것처럼 이온성 분 가운데 주로 $\mathrm{Na}^{+}, \mathrm{NH}_{4}^{+}, \mathrm{Cl}^{-}, \mathrm{HCO}_{2}^{-}, \mathrm{CH}_{3} \mathrm{CO}_{2}^{-}$성 분들이 실험실 실내환경과 실험자에 의해 쉽게 오염 될 가능성이 있음을 보여주고 있다. ${ }^{23}$ 따라서 이러한 

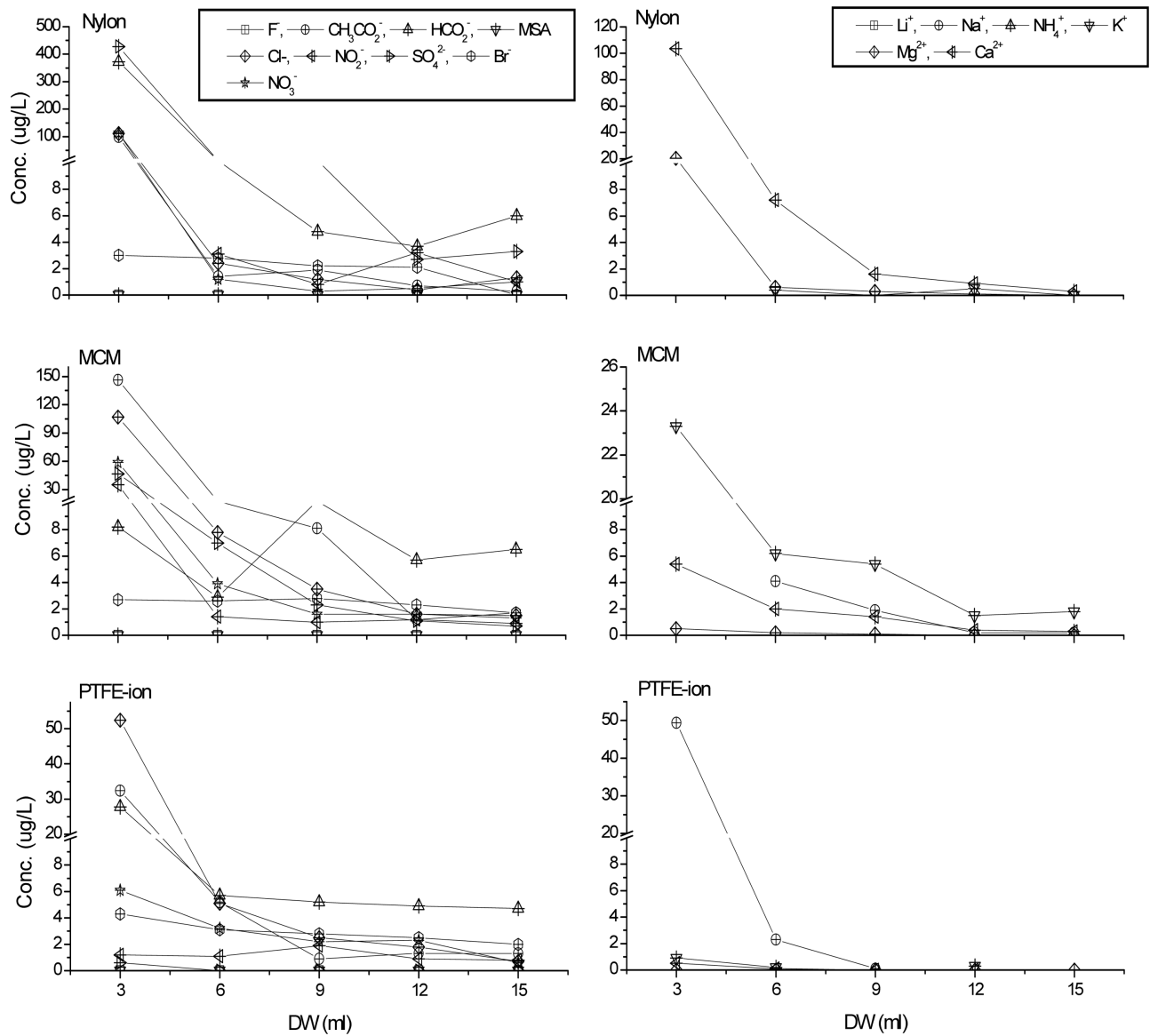

Fig. 3. The concentration variations of ionic species from filtrate according to the washing DW volume.

이온성분들에 대한 오염영향을 줄이기 위해서는 증 류수의 관리와 실험도구의 세척 및 관리 등 실험 과 정상의 세심한 주의가 요구된다. 이온성분 가운데 $\mathrm{NO}_{3}{ }^{-}$의 바탕시험 결과는 본 연구에서 적용된 눈 시 료 채취 시료 병의 산세척법 영향으로 판단된다. 또 한 이온성분을 측정하는 청정실험실의 $\mathrm{HNO}_{3}$ 시약에 서 발생하는 흠(Fume) 가스에 의한 영향을 고려해야 한다. 따라서 이를 개선하기 위해서는 이온성분 측정 용 시료 병의 세척 시 증류수를 이용한 세척법을 고 려해야한다. 그리고 실험실 내부에 $\mathrm{HNO}_{3}$ 시약을 보 관 시 오염관리가 필요한 것으로 조사되었다.

\section{3. 필터시험}

Fig. 3은 대표적인 수용성 필터(Nylon, MCM, PTFEion 전용)들을 이용하여 증류수 $(3 \mathrm{~mL} /$ 회 $)$ 에 의해 용 출되는 이온성분을 측정하여 서로 비교한 것이다. 연 구 결과 최초 $3 \mathrm{~mL}$ 흘려준 후 포집한 용액의 음, 양
이온의 농도는 수십-수백 $\mu \mathrm{g} / \mathrm{L}$ 로 측정되었다. 그렇지 만 본 연구에서 조사한 3 종류 필터 모두 증류수에 의한 용출횟수가 증가함에 따라 용출액 이온성분들 의 농도는 점차 낮아지는 것으로 나타났다. 특히 6 $\mathrm{mL}$ 의 증류수를 흘려주는 경우 필터 용출액의 이온성 분들의 농도는 $1-5 \mu \mathrm{g} / \mathrm{L}$ 수준으로 감소하였다. 시험 필터 가운데 PTFE-ion 전용 필터가 다른 필터들에 비해 오염영향이 비교적 낮은 것으로 나타났다. 그렇 지만 증류수를 이용하여 지속해서 흘려주더라도 특 히 음이온 성분들의 농도는 양이온 성분들과 달리 뚜 렷하게 감소하지 않는 것으로 나타났다.

따라서 눈과 빙하 용융액의 불용성 입자들을 제거 하기 위해 필터를 세척하지 않고 직접 시료에 적용할 경우 시료의 이온성분 농도 값은 필터 자체로부터 용 출된 이온성분들의 영향을 받을 수 있다. 특히 sub $\mu \mathrm{g} / \mathrm{L} \sim \mu \mathrm{g} / \mathrm{L}$ 수준의 시료의 이온성분 측정에는 필터 과정을 적용하기가 어려울 것으로 판단된다. Table 2 
360 Sang-bum Hong, Soon-do Hur, Sun-Mee Kim, Sungmin Hong, Ji-woong Chung, Namgoo Kang and Chang-Hee Kang

에서 제시한 지역별 눈 시료 이온성분들의 농도 분포 를 고려하면 기기 분석 전에 시료 용융액에 대한 필 터 적용은 시료채취 지역에 따라 신중해야 한다. 특 히 남극과 그린란드 지역 눈 시료의 이온성분의 농도 분포를 고려하면 일부 양이온 $\left(\mathrm{NH}_{4}^{+}, \mathrm{K}^{+}, \mathrm{Mg}^{2+}, \mathrm{Ca}^{2+}\right)$ 성분들과 음이온 $\left(\mathrm{CH}_{3} \mathrm{CO}_{2}^{-}, \mathrm{HCO}_{2}^{-}\right)$성분들은 필터 과정에서 오염가능성이 예상된다. 시료의 이온성분들 의 농도와 불용성 입자의 농도가 비교적 높은 중위도 고산지역에서 채취한 눈 시료의 경우는 분석 전에 필 터를 이용하여 불용성 입자들을 제거하는 과정이 필 요하다(Table 2). 그렇지만 시료의 양이 매우 소량인 경우는 필터 과정에서 시료 일부가 소비될 수 있으므 로 시료 소모를 줄이기 위해서는 필터 과정을 생략하 는 것이 바람직하다. ${ }^{17}$

\subsection{NEEM 캠프 눈 시료 이온성분 측정자료의 불확도 계산}

이온성분의 측정자료 불확도를 결정하기 위해 눈 시료 이온성분 측정의 불확도 요인들을 조사하였다. 본 연구에서는 이온성분 가운데 $\mathrm{F}^{-}$성분에 대해 시험 적으로 연구하였다. 눈 시료 이온성분 측정과정은 현 장 시료 채취, 시료 전처리(용융 및 분취), IC 시스템 을 이용한 기기분석 과정의 3 개 주요 과정으로 구분
할 수 있다. Table 8은 우진춘 등(2005)이 제시한 화 학분석의 주요 불확도 요인을 토대로 이러한 3 개의 주요 실험과정에서 발생할 수 있는 다양한 불확도 요 인들을 정리한 것이다. 이 가운데 시료채취 과정의 불확도 요인들은 $u-1, u-2, u-3, u-4$ 등으로 구분할 수 있다. 시료 전처리 과정에서 발생하는 불확도 요인들 은 $u-5$ 와 $u-6$, 마지막으로 기기분석과정의 불확도 요 인들은 $u-7, u-8, u-9$ 등이 있다.

Table 8에 제시된 요인별 표준 불확도 평가 방법을 검토하면 시료채취 과정에서 발생할 수 있는 불확도 요인 가운데 $u-2$ 요인은 시료 채취지점 주변에 특정 오염 배출원이 없고 시료채취 지역의 눈의 적설이 비 교적 균일하게 이뤄질 때 무시할 수 있을 것으로 판 단된다. 그리고 시료의 채취와 용융과정에서 발생하 는 $u-1, u-3, u-4, u-5, u-6$ 의 요인들에 기인한 불확도 는 바탕시료(blank test) 분석 결과를 이용하여 A형 불확도 방법으로 평가할 수 있다. $\mathrm{F}^{-}$의 경우 바탕시 료 분석결과 측정 시스템의 검출한계 이하로 검출되 었으므로 $\mathrm{F}^{-}$의 농도에 미친 바탕시료에 의한 불확도 는 무시하였다(3.2절).

$\mathrm{F}^{-}$저장 표준물질의 표준불확도와 상대표준불확도 의 계산은 제조사의 인증서로부터 물질의 순도를 확 인하여 계산하였으며 Table 9에 정리하였다. 이때 저

Table 8. Parameters and sources of measurement uncertainties

\begin{tabular}{|c|c|c|}
\hline & Uncertainty parameters & Sources \\
\hline$u-1$ & The cleanliness of sampling bottle and tools & The possibility of contamination from sampling bottle and tools \\
\hline$u-2$ & The heterogeneity of snow samples & The heterogeneity of snow samples at the sampling site in the field \\
\hline$u-3$ & Snow sampling in the field & Uncareful use of sampling tools by operator during sampling \\
\hline$u-4$ & Snow sample storage and transportation & $\begin{array}{l}\text { The difference of measurement time using analytical system and sam- } \\
\text { pling time in the field }\end{array}$ \\
\hline$u-5$ & Melting of snow sample & $\begin{array}{l}\text { The possibility of contamination during melting of snow samples in } \\
\text { the labaratory }\end{array}$ \\
\hline$u-6$ & Fractionization of melted sample & $\begin{array}{l}\text { The possibility of contamination during the fractionization of melted } \\
\text { samples }\end{array}$ \\
\hline$u-7$ & Preparation of standard solution & $\begin{array}{l}\text { The combination of difference of matrix between standard and sam- } \\
\text { ple, uncertainty of equipments to dilute stock standard solution, } \\
\text { uncertainty of stock standard solution caused by preparation of } \\
\text { maker and stability of stock standard solution }\end{array}$ \\
\hline$u-8$ & $\begin{array}{l}\text { Quantification process of analytical result using } \\
\text { calibration curve }\end{array}$ & The linearity of calibration curve \\
\hline$u-9$ & Measurement system during measurement & The repeatability and drift of measurement system \\
\hline
\end{tabular}

Table 9. Uncertainty of purity of $\mathrm{F}^{-}$

\begin{tabular}{cccc}
\hline \hline Analyte & Concentration $(\mathrm{mg} / \mathrm{L})$ & Standard uncertainty & Relative standard uncertainty \\
\hline $\mathrm{F}^{-}$ & $20.2 \pm 0.202$ & 0.082 & 0.004082 \\
\hline
\end{tabular}


Table 10. Relative standard uncertainties of diluted standard solutions and standard preparation

\begin{tabular}{|c|c|c|c|c|c|c|c|c|c|c|c|c|c|}
\hline Analyte & Conc. & $\mathrm{U}_{\mathrm{r} \text { purity(S) }}$ & $\mathrm{U}_{\mathrm{r} \text { flask }}$ & $\mathrm{U}_{\mathrm{r} \text { syringe }}$ & $\mathrm{U}_{\mathrm{r} \mathrm{std}(\mathrm{W} 1)}$ & $\mathrm{U}_{\mathrm{r} \mathrm{std}(\mathrm{W} 2)}$ & $\mathrm{U}_{\mathrm{r} \mathrm{std}(\mathrm{W} 3)}$ & $\mathrm{U}_{\mathrm{r} \mathrm{std}(\mathrm{W} 4)}$ & $\mathrm{U}_{\mathrm{r} \mathrm{std}(\mathrm{W} 5)}$ & $\mathrm{U}_{\mathrm{r} \mathrm{std}(\mathrm{W} 6)}$ & $\mathrm{U}_{\mathrm{r} \mathrm{std}(\mathrm{W} 7)}$ & $\mathrm{U}_{\mathrm{r} \mathrm{std}(\mathrm{W} 8)}$ & $\mathrm{U}_{\mathrm{r} \text { std }}$ \\
\hline \multirow[t]{10}{*}{$\mathrm{F}^{-}$} & 20.2 & 0.004082 & & & & & & & & & & & \\
\hline & 1.01 & 0.004082 & 0.00577 & 0.005774 & 0.009129 & & & & & & & & \\
\hline & 0.101 & & 0.00577 & 0.005774 & 0.009129 & 0.012247 & & & & & & & \\
\hline & 0.0505 & & 0.00577 & 0.005774 & & 0.012247 & 0.01472 & & & & & & \\
\hline & 0.0202 & & 0.00577 & 0.005774 & & & 0.01472 & 0.016833 & & & & & \\
\hline & 0.0101 & & 0.00577 & 0.005774 & & & & 0.016833 & 0.018708 & & & & \\
\hline & 0.00505 & & 0.00577 & 0.005774 & & & & & 0.018708 & 0.020412 & & & \\
\hline & 0.00101 & & 0.00577 & 0.005774 & & & & & & 0.020412 & 0.021985 & & \\
\hline & 0.000101 & & 0.00577 & 0.005774 & & & & & & & 0.021985 & 0.023452 & \\
\hline & & & & & 0.009129 & 0.012247 & 0.01472 & 0.016833 & 0.018708 & 0.020412 & 0.021985 & 0.023452 & 0.050332 \\
\hline
\end{tabular}

장 표준물질의 순도에 적용된 표준불확도는 삼각형 분포에 따르는 B형 불확도 평가 방법을 이용하였다. 그리고 사용만기일과 보관방법을 준수하였으므로 시 료의 안정성에 기인한 불확도는 무시할 수 있다.

검정곡선 작성용 표준용액의 조제과정에서 발생하 는 불확도는 저장용 표준 용액의 불확도와 희석과정 에 사용하는 도구들(syringe, volumetric flask)의 불확 도를 결합하여 평가하였다. 희석에 사용한 주사기 (syringe)에 의한 불확도는 교정 성적서를 근거로 사 각형 분포에 따라 B형 불확도 평가 방법을 이용하였 다. 용량플라스크의 경우 교정 성적서를 근거로 사각 형 분포에 따르는 $\mathrm{B}$ 형 불확도 평가 결과와 용매 온 도에 따른 부피 팽창으로 발생하는 불확도 요인을 결 합하여 계산하였다(Table 9). 시료측정에 적용하고자 하는 검정곡선 작성용 표준시료와 측정시료 간의 매 질 등에 의해 측정량의 차이를 수반할 수 있다. 본 연구에서는 눈 시료 용융액과 증류수 매질의 차이가 거의 없다고 가정하였고 측정시료 매질에 의한 간섭 효과는 무시하였다.

검정곡선의 직선성에 의한 불확도는 검정곡선에 의해서 결정된 측정 결과 값 $\left(\mathrm{X}_{\mathrm{i}}\right)$ 의 주요한 불확도 요 인이다. 검정곡선은 3 개 농도 $(0.10,1.01,5.05 \mu \mathrm{g} / \mathrm{L})$ 의 표준용액을 3 회 분석하여 작성하였으며 실제 측 정자료를 이용하여 농도 값으로 환산하였다. 검정곡 선은 결정계수 $\left(\mathrm{r}^{2}\right)$ 가 0.9992 , 기울기는 $0.063, \mathrm{y}$-절편 은 -0.0007 의 값을 나타내었다. 작성된 검정곡선에 의해 이들 3 개의 표준용액 농도를 계산한 결과 0.17 , $0.93,5.07 \mu \mathrm{g} / \mathrm{L}$ 으로 조사되었다. 선형 최소제곱법으 로 작성한 검정곡선에 의한 불확도는 식 (2)에 의해 계산한 결과 각각의 농도 수준에서 $0.103,0.093$, $0.123 \mu \mathrm{g} / \mathrm{L}$ 이었다. 따라서 3 개의 농도 수준에서 검정 곡선에 대한 상대표준불확도는 각각 $1.019,0.092$,
0.024 이다.

$$
\begin{aligned}
& \mathrm{S}_{\mathrm{c}}=\frac{\mathrm{S}_{\mathrm{r}}}{\mathrm{m}} \sqrt{\frac{1}{\mathrm{M}}+\frac{1}{\mathrm{~N}}+\frac{\left(\overline{\mathrm{y}_{\mathrm{c}}}-\mathrm{y}\right)^{2}}{\mathrm{~m}^{2} \mathrm{~S}_{\mathrm{xx}}}} \\
& \mathrm{S}_{\mathrm{r}}=\sqrt{\frac{\mathrm{S}_{\mathrm{yy}}-\mathrm{m}^{2} \mathrm{~S}_{\mathrm{xx}}}{\mathrm{N}-2}, \mathrm{~S}_{\mathrm{yy}}=\sum\left(\mathrm{y}_{\mathrm{i}}-\overline{\mathrm{y}}\right)^{2}, \mathrm{~S}_{\mathrm{xx}}=\sum\left(\mathrm{x}_{\mathrm{i}}-\overline{\mathrm{x}}\right)^{2}} \\
& \overline{\mathrm{x}}=\frac{\sum \mathrm{x}}{\mathrm{N}}, \overline{\mathrm{y}}=\frac{\sum \mathrm{y}_{\mathrm{i}}}{\mathrm{N}}
\end{aligned}
$$

$\mathrm{m}$ : Slope of regression line, M: Number of measurements, N: Number of standards for the calibration

$\overline{y_{c}}:$ Signal of target species

IC 시스템의 재현성과 변동성의 불확도는 표준물 질의 반복 측정 자료를 이용하여 $\mathrm{A}$ 형 불확도 평가 방법으로 계산하였다. 재현성은 시료 분석 전에 측 정한 표준용액 $(10 \mu \mathrm{g} / \mathrm{L})$ 의 3 회 연속 측정 결과를 이용하였으며 변동성은 전체 시료 분석 기간 $(45$ $\mathrm{hr}$ ) 동안 4-5 hr 간격으로 측정한 결과를 이용하였 다. 조사 결과 재현성에 의한 불확도는 표준불확도 가 0.0507 , 상대표준불확도가 0.0051 , 변동성은 표 준불확도가 0.0245 , 상대표준불확도가 0.0025 로 나 타났다.

앞서 2.5절에서 제시한 관계식 (1)의 각각의 입력 량의 불확도가 서로 상관성이 없는 경우 합성표준불 확도(Combined standard uncertainty)는 Taylor 급수 전개에 의한 불확도 전파 법칙을 이용하여 식 (3)에 의해 계산할 수 있다. 이때 식 (1)과 같이 입력량이 곱과 나누기로 이루어진 경우는 식 (4)로 변환할 수 있으므로 측정자료 $\left(C_{i}\right)$ 의 합성표준불확도 $\left(u_{c}\left(C_{i}\right)\right)$ 를 구 할 수 있다. 계산 결과 각각의 측정 농도 $(0.17,0.93$, $5.07 \mu \mathrm{g} / \mathrm{L})$ 의 합성표준불확도는 $0.10,0.10,0.29 \mu \mathrm{g} /$ $\mathrm{L}$ 로 나타났다. 


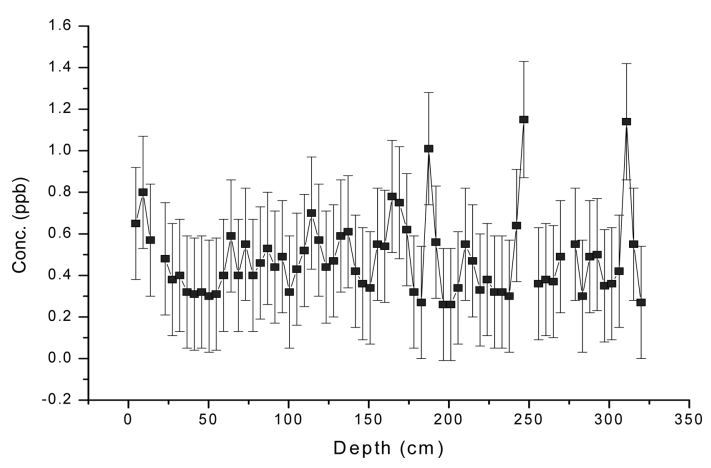

Fig. 4. The concentration variations of $\mathrm{F}^{-}$with expanded uncertainties ( $\mathrm{k}=2, \sim 95 \%$ confidence level) on the depth of NEEM snowpit samples.

$$
\begin{aligned}
& U_{c}^{2}(y)=\sum_{i=1}^{N}\left(\frac{\partial f}{\partial x_{i}}\right)^{2} u^{2}\left(x_{i}\right) \\
& \left(\frac{u_{c}\left(C_{i}\right)}{C_{i}}\right)^{2}=\left(\frac{u\left(X_{i}\right)}{X_{i}}\right)^{2}+\left(\frac{u\left(f_{1}\right)}{f_{1}}\right)^{2}+\left(\frac{u\left(f_{2}\right)}{f_{2}}\right)^{2}+\left(\frac{u\left(f_{3}\right)}{f_{3}}\right)^{2}
\end{aligned}
$$

이때 $\frac{\partial \mathrm{f}}{\partial \mathrm{x}_{\mathrm{i}}}$ 는 측정 관계식을 입력량 $\mathrm{x}_{\mathrm{i}}$ 로 편미분한 것으로서 감도 계수(sensitivity coefficient)이다. 측정 값의 확장불확도(Expanded uncertainty: $u_{E}\left(C_{i}\right)$ )를 계 산하기 위해서는 신뢰 수준에 상당하는 포함 인자 $k$ 를 곱하여 식 (5)에 따라 구한다.

$$
\mathrm{U}=\mathrm{k} \cdot \mathrm{u}_{\mathrm{c}}
$$

포함 인자 $k$ 를 계산하기 위해서는 합성표준불확도 의 유효 자유도를 직접 계산하여 $\mathrm{t}$-분포표를 이용하 거나 최종결과의 자유도가 큰 경우, $95 \%$ 또는 $99 \%$ 신뢰 수준의 값으로 $k=2$ 또는 3 이 각각 사용될 수 있다. 본 연구에서는 시료의 $\mathrm{F}^{-}$농도 값의 불확도 산 정에 고려된 불확도 요인들 간에 상관관계가 존재하 지 않으며, 각 요인의 감도 계수는 모두 1 로 가정하 였다. 또한 시료의 $\mathrm{F}^{-}$농도 값의 분포가 $\mathrm{t}$-분포를 따 르고 유효 자유도가 무한대라고 가정하거나 혹은 정 규분포를 따르고 유효 자유도가 충분히 크다고 가정 하였다. 최종적인 측정 불확도의 표현은 약 $95 \%$ 신 뢰 수준으로 $k=2$ 를 합성표준불확도에 곱하여 확장불 확도로 계산하였고 각각 $0.21,0.21,0.57 \mu \mathrm{g} / \mathrm{L}$ 로 나 타났다. 결국 시료의 $\mathrm{F}^{-}$농도 값을 약 $95 \%$ 신뢰 수 준으로 불확도를 포함하여 표기하면 각각 $(0.17 \pm 0.21)$, $(0.93 \pm 0.21),(5.07 \pm 0.57) \mu \mathrm{g} / \mathrm{L}(k=2$, 약 $95 \%$ 신뢰 수준 $)$ 이다. Fig. 4는 이와 같은 방법으로 실제 NEEM 캠 프 현장의 눈 시료 이온성분 가운데 $\mathrm{F}^{-}$의 농도에 대 한 확장불확도를 계산한 후 깊이에 따른 농도 변화를
나타낸 것이다.

\section{4. 결 론}

극 지역 눈과 빙하시료는 시료의 특성과 이온성분 의 낮은 농도 범위(sub-ug/L sub-mg/L) 때문에 측정 방법의 선정과 측정시스템의 성능이 매우 중요하다. 본 연구에서는 IC 시스템의 성능평가 및 주요 실험 과정, 측정자료의 불확도 산출법 연구를 통해 극 지 역 눈과 빙하시료의 이온성분 측정법을 개발하고자 하였다. 이를 위해 다양한 극 지역 눈과 빙하시료의 이온성분 측정결과와 IC 시스템의 성능 평가 결과와 비교하였다. 연구 결과 현재 운영 중인 IC 시스템의 성능은 극 지역 눈과 빙하시료의 이온성분을 측정하 기에 적합한 것으로 나타났다. 그렇지만 눈과 빙하시 료의 미량 이온성분을 정량 분석하기 위해서는 IC 시스템의 성능뿐만 아니라 전체 실험과정에 대한 관 리가 중요한 것으로 나타났다. 시료 병에 대한 실험 실 바탕시험 결과 유기음이온 성분을 포함한 일부 이 온성분들은 실험실 환경에서 오염 가능성이 있다. 특 히 세척과정에서 산 용액 $\left(0.1 \% \mathrm{HNO}_{3}\right)$ 을 사용한 눈 시료 채취 병에 의한 오염가능성은 이온성분 분석용 시료 병보다 높은 것으로 나타났다. 따라서 이온성분 측정을 위한 눈 시료 채취 병은 세척 과정을 증류수 를 이용하는 방법으로 개선할 필요가 있다. 또한 시 료 병은 동일한 세척법이 적용된 시료 병을 이용하여 실험실과 현장 바탕시험을 수행해야 한다. 특히 산 용액으로 세척된 시료병은 산 용액 함침 기간에 따라 바탕시험 결과가 다르게 나타날 수 있기 때문에 동일 한 함침 기간이 적용된 시료 병을 이용해야 한다. 그 럼으로써 측정자료에 미칠 수 있는 시료 병의 오염영 향을 체계적으로 관리해야한다. 시료 용융액의 불용 성 입자 제거를 위해 필터를 사용하면 여과과정에서 필터로부터 용출된 이온성분에 의해 오염가능성이 있다. 따라서 필터를 이용하여 용융시료를 여과하기 전에 증류수 $(\sim 6 \mathrm{~mL})$ 로 세척해야하고 시료의 농도특 성에 따라 선별적으로 적용해야한다. 마지막으로 그 린란드 북서부 내륙의 NEEM 캠프 풍상지역에서 채 취한 눈 시료 이온성분들의 측정불확도를 결정하기 위하여 $\mathrm{F}^{-}$성분의 측정자료를 이용하여 불확도 산출 법을 개발하였다. 연구결과 눈 시료의 $\mathrm{F}^{-}$농도 값을 약 $95 \%$ 신뢰 수준으로 불확도를 포함하여 표기하면 각각 $(0.17 \pm 0.21),(0.93 \pm 0.21),(5.07 \pm 0.57) \mu \mathrm{g} / \mathrm{L}(k=2$, 약 $95 \%$ 신뢰 수준)으로 나타났다. 따라서 3 개 농도 
수준의 측정자료는 각각 $123.5 \%, 22.6 \%, 11.2 \%$ 의 오 차범위를 보이는 것으로 나타났다. 특히 정량한계 부 근의 농도 수준에서 측정자료의 불확도가 가장 큰 것 을 알 수 있다.

\section{감사의 글}

이 연구는 극지연구소 기관고유 정책 연구비 (PE12070)의 지원으로 수행되었습니다.

\section{참고문헌}

1. S.-B. Hong, D.-S. Jung, S.-B. Lee, D. -E. Lee, S.-H. Shin and C.-H. Kang, Anal. Sci. Technol., 24(1), 2437 (2011).

2. Scientific committee on Antarctic Research, 'Antarctic climate change and the environment', J. Turner, R. Bindschadler, P. Convey, G. Prisco, E. Fahrbach, J. Gutt, D. Hodgson, P. Mayewski and C. Summerhayes, Ed., Victoire Press, Cambridge, 2009.

3. F. Lambert, B. Delmonte, J. R. Petit, M. Bigler, P. R. Kaufmann, M. A. Hutterli, T. F. Stocker, U. Ruth, J. P. Steffensen and V. Maggi, Nature Letters, 452(3), 616619 (2008).

4. S. Olivier, M. Schwikowski, S. Brütsch, S. Eyrikh, H. W. Gäggeler, M. Lüthi, T. Papina, M. Saurer, U. Schotterer, L. Tobler and E. Vogel. Geophys. Res. Lett., 30(19), 2019, doi:10.1029/2003GL018290 (2003).

5. R. Rothlisberger, M. Bigler, M. Hutterli, S. Sommer, B. Stauffer, H. G. Junghans and D. Wagenbach, Environ. Sci. Technol., 34(2), 338-342 (2000).

6. J. Ivask, J. Pentchuk and R. Vaikmae, Proc., Estonian Acad. Sci. Chem., 50(1), 46-51 (2001).

7. J. Cole-Dai, D. M. Budner and D. G. Ferris, Environ. Sci. Technol., 40, 6764-6769 (2006).

8. T. Jauhianinen, J. Moore, P. Peramaki, J. Derome and K. Derome, Anal. Chim. Acta., 389, 21-29 (1999).
9. E. C. Osterberg, M. J. Handley, S. B. Sneed, P. A. Mayewski and K. J. Kreutz, Environ. Sci. Technol., 40(10), 3355-3361 (2006).

10. A. Eichler, M. Schwikowski, H. W. Gäggeler, V. Furrer, H. A. Synal, J. Beer, M. Saurer and M. Funk, J. Glaciol., 46(154), 507-515 (2000).

11. K. J. Kreutz, V. B. Aizen, D. Cecil and C. P. Wake, J. Glaciol., 47(150), 548-554 (2001).

12. P. A. Mayewski and S. Whitlow. 1997. Regional survey of Greenland, 1988, snow pit data. Boulder, CO: National Snow and Ice Data Center. Digital media.

13. S. Whitlow, P. A. Mayewski and J. E. Dibb, Atmos. Environ., 26A(11), 2045-2054 (1992).

14. P. A. Mayewski and D. A. Dixon, 2005. US International Trans-Antarctic Scientific Expedition (US ITASE) glaciochemical data. Boulder, CO, USA: National Snow and Ice Data Center. Digital media.

15. P. A. Mayewski and S. Whitlow, 2000. Dronning Maud Land, Antarctica, ice core, 1991 and 1992. Boulder, CO: National Snow and Ice Data Center. Digital media.

16. S. Kang, P. A. Mayewski, D. Qin, S. A. Sneed, J. Ren and D. Zhang, Atmos. Environ., 38, 2819-2829 (2004).

17. M. A. J. Curran and A. S. Palmer, J. Chromatogr. A., 919, 107-113 (2001).

18. T. M. Huber, M. Schwikowski and H. W. Gaggeler, $J$. Chromatogr. A., 920, 193-200 (2001).

19. J.-C. Woo, S.-H. Oh, B.-M. Kim, H.-K. Bae, K.-S. Kim and Y.-D. Kim, Anal. Sci. Technol., 18(6), 475-482 (2005).

20. S. Hong, A. Liuberas and F. Rodriguez, Kor. J. Pol. Res., 11, 35 (2000).

21. 김진영, 정재철, 서승일, 서용준, 이정직, 김종상, 인문교, Yakhak Hoeji., 52(6), 480-487 (2008).

22. A. Morganti, S. Becagli, E. Castellano, M. Severi, R. Traversi and R. Udisti, Anal. Chim. Acta., 603, 190-198 (2007).

23. M. L. Siggaard-Anderssen, J. P. Steffensen and H. Fischer, Annal. Glaciol., 35, 243-249 (2002). 